\title{
Glottic Cancer pT0 TNM Finding v6 and v7
}

National Cancer Institute

\section{Source}

National Cancer Institute. Glottic Cancer pTO TNM Finding v6 and v7. NCI Thesaurus.

Code C64671.

Glottic cancer with no evidence of a primary tumor. (from AJCC 6th and 7th Eds.) 